\title{
MITRAL VALVE ANNULOPLASTY WITH A BOVINE PERICARDIAL STRIP - 18-YEAR RESULTS
}

\author{
Pablo Maria Alberto Pomerantzeff, Carlos Manuel de Almeida Brandão, João \\ Marcelo Ancilon Albuquerque, Paola Yastrevov Pomerantzeff, Flavio Takeda, and \\ Sergio A. Oliveira
}

Pomerantzeff PMA, Brandão CM de A, Albuquerque JMA, Pomerantzeff PY, Takeda F, Oliveira SA. Mitral valve annuloplasty with a bovine pericardial strip - 18-year results. Clinics. 60(4):305-10.

PURPOSE: Prosthetic annuloplasty rings are currently used in mitral reconstruction. Posterior annuloplasty with a bovine pericardial strip is a technique largely used in the Heart Institute of University of São Paulo Medical School. The purpose of the study was to analyze the late results of mitral valve repair with posterior annuloplasty using a bovine pericardial strip. METHODS: Between January 1984 and December 2002, 273 patients underwent mitral valve repair with posterior pericardial annuloplasty in the Heart Institute of University of São Paulo Medical School. One hundred and forty four (52.7\%) were women and ages ranged between 1 and 76 years $(38.3 \pm 21.1)$. Rheumatic fever was present in $52.0 \%$ of the patients. Associated techniques were employed in $26.0 \%$ of the patients, and the most frequent was chordal shortening (9.2\%).

RESULTS: Hospital mortality was 3.3\% (9 patients), with the major cause being low cardiac output (6 patients). Actuarial survival was $55.1 \% \pm 16.8 \%$ in 18 years. During the 18-year follow-up: patients were free from the following: reoperation $(59.1 \% \pm \pm 13.9 \%$, (percent $+/$ - Standard Error), thromboembolism $(97.4 \% \pm 2.3 \%)$, hemolysis $(99.2 \% \pm 0.2 \%)$, and endocarditis $(99.6 \% \pm 1.0 \%)$. In the late follow-up period, $83.9 \%$ were classified as New York Heart Association functional class I.

CONCLUSIONS: Late results with mitral valve repair with posterior annuloplasty using a bovine pericardial strip were satisfactory. The technique is feasible, reproducible, and cost effective.

KEYWORDS: Mitral valve. Annuloplasty.Valve surgery. Bovine pericardium. Valve repair.

Mitral valve repair (MVR) has been established as an excellent procedure for treating mitral regurgitation. ${ }^{1} \mathrm{~A}$ number of studies have shown the importance of preserving the anatomic characteristics of the mitral annulus..$_{2}$ Posterior annuloplasty of the mitral valve can be performed with rigid or flexible materials, and both techniques appear to produce better results than mitral valve replacement. ${ }^{3-6}$ The purpose of this study was to analyze the late results of posterior annuloplasty using a bovine pericardial strip.

Heart Institute (INCOR), Hospital das Clínicas, Faculty of Medicine, University of São Paulo - São Paulo/SP, Brazil.

E-mail: dcipablo@incor.usp.br

Received for publication on February 25, 2005. Accepted for publication on May 05, 2005.

\section{MATERIALS AND METHODS}

Between January 1984 and December 2002, 273 consecutive patients with mitral regurgitation underwent mitral valve repair with posterior annuloplasty using a bovine pericardial strip (Figure 1). We excluded patients who had undergone other procedures in the posterior annulus. All procedures were approved by the Scientific Committee of the Heart Institute of University of São Paulo Medical School, and informed consent was obtained from each patient.

The patients ranged in age between 1 and 76 years, with an average age of 38.3 years and a standard deviation of 21.1 years. One hundred and forty four $(52.7 \%)$ patients were women and $129(47.3 \%)$ were men. According to the New York Heart Association (NYHA) classification, 25 (9.3\%) patients were in functional class II; 138 (50.4\%) in class III, and 110 (40.3\%) in class IV. Rheumatic fever was 

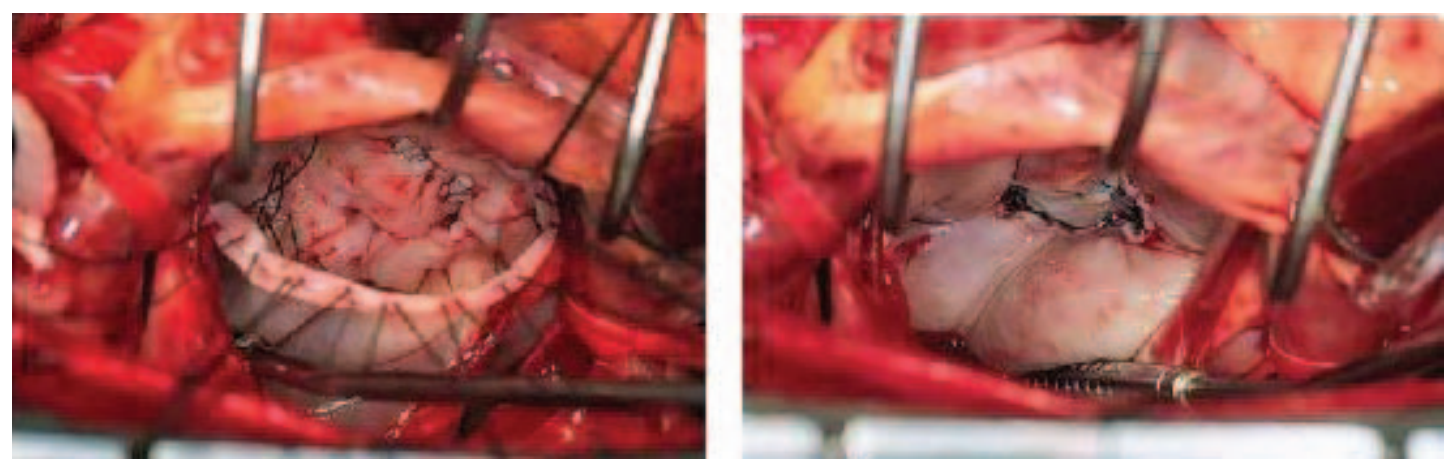

Figure 1 - Technique of posterior annuloplasty with bovine pericardial strip

present in $142(52.0 \%)$ patients. The other causes of mitral valve disease were ischemia in $34(12.4 \%)$, degenerative disease in $23(8.5 \%)$, congenital malformations in 17 $(6.2 \%)$, cardiomyopathy in $11(3.9 \%)$, endocarditis in 8 (3.1\%), unknown in 15 (5.4\%), and other in 23 (8.5\%).

Associated techniques of valve repair were employed in 71 patients $(26.0 \%)$. Chordal shortening was employed in $25(9.2 \%)$ patients, papillary muscle splitting in 15 $(5.5 \%)$, anterior leaflet resection in $11(4.0 \%)$, chordal resection in $6(2.2 \%)$, decalcification in $4(1.5 \%)$, cleft suture in $4(1.5 \%)$, papillary shortening in $2(0.7 \%)$, leaflet thinning in $2(0.7 \%)$, chordal transposition in $1(0.3 \%)$, and anterior leaflet plication in $1(0.3 \%)$.

Associated procedures were performed in 137 (50.2\%) patients. Aortic valve replacement was performed in 57 (20.9\%) patients, tricuspid annuloplasty in $36(13.2 \%)$ patients, coronary artery bypass graft in $29(10.6 \%)$ patients, aortic valve repair in $6(2.2 \%)$, aortic valve commissurotomy in $5(1.8 \%)$, atrial septal defect closure in $3(1.1 \%)$, and left ventricular myectomy in $1(0.3 \%)$.

Postoperative follow-up was obtained by contact with the patients through scheduled hospital visits, telephone calls, or questionnaires sent by mail. Data are presented according to the revised rules for data and nomenclature presentation. ${ }^{7}$

\section{RESULTS}

The hospital mortality was 3.3\% (9 patients), and the main cause was low cardiac output (6 patients). Two of these patients were children undergoing surgery for active rheumatic carditis. The other 3 patients presented multiple organ failure.

One patient presented persistent mitral regurgitation and underwent valve replacement on the $27^{\text {nd }}$ day of the postoperative period. One patient presented endocarditis and was treated clinically with good evolution.

During the late postoperative period, 8 (3.0\%) patients died. The causes of late mortality were congestive heart failure (3), stroke (2), unknown (2), and myocardial infarction (1). Linearized rates of late events are presented in Table 1.
Table 1 - Linearized rates of late events

\begin{tabular}{lcc}
\hline EVENTS & PATIENTS & $\begin{array}{c}\text { LINEARIZED RATES } \\
(\% \text { patient-year })\end{array}$ \\
\hline Endocarditis & 1 & 0.2 \\
Thromboembolism & 3 & 0.6 \\
Hemolysis & 2 & 0.4 \\
Reoperation & 13 & 2.7 \\
\hline
\end{tabular}

Actuarial survival was $55.1 \% \pm 16.8 \%$ (mean $\pm \mathrm{SD}$ ) in 18 years (Figure 2). Freedom from reoperation was 59.1\% $\pm 13.9 \%$ (Figure 3), freedom from thromboembolism was $97.4 \% \pm 2.3 \%$ (Figure 4), freedom from hemolysis was $99.2 \%$ $\pm 0.2 \%$ (Figure 5) and freedom from endocarditis was $99.6 \%$ $\pm 1.0 \%$ in 18 years (Figure 6 ).

Follow-up was $85.1 \%$ complete (5993 months/ patients). In the late follow-up period, 215 patients $(83.9 \%)$ were in NYHA functional class I, $22(8.6 \%)$ were in class II, 18 $(7.1 \%)$ were in class III, and $1(0.4 \%)$ was in class IV.

\section{DISCUSSION}

In Brazil, valve procedures represent at least $30 \%$ of cardiac operations, and the primary cause of valve disease is rheumatic fever. ${ }^{8}$ In this series, rheumatic fever was present in 52\% of the patients. According to David ${ }^{9}$ and Antunes, ${ }^{10}$ mitral valve repair in rheumatic patients is a better operation than mitral valve replacement when repair is feasible, because it results in lower immediate and late mortality rates and lower risk of valve-related events. In a previously published series, late results with mitral valve repair in rheumatic patients were satisfactory, especially in patients older than 16 years, who presented lower rates of reoperation in late evolution. ${ }^{11}$

Our hospital mortality was low; at 9 patients, 2 of which had undergone surgery for active rheumatic carditis, which is associated with higher morbidity and mortality. ${ }^{12}$ Longterm survival has been satisfactory, similar to that reported with flexible ring annuloplasty. ${ }^{13}$

The use of flexible materials to perform valve annuloplasty 


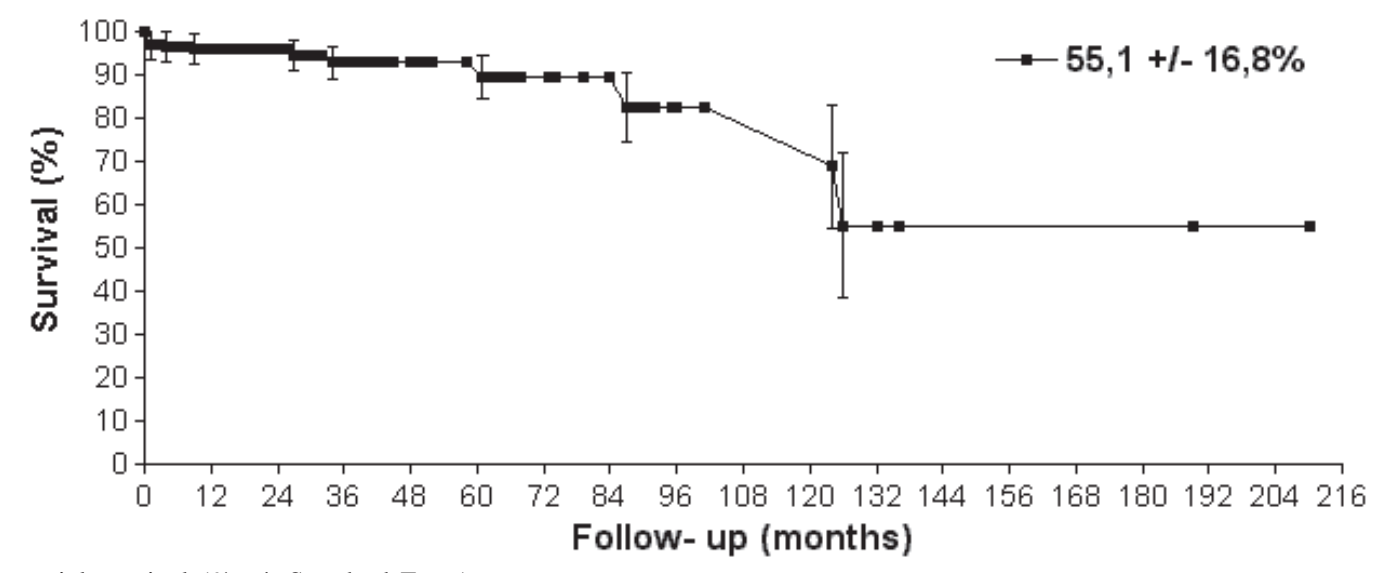

Figure 2 - Actuarial survival $(\%+/-$ Standard Error $)$

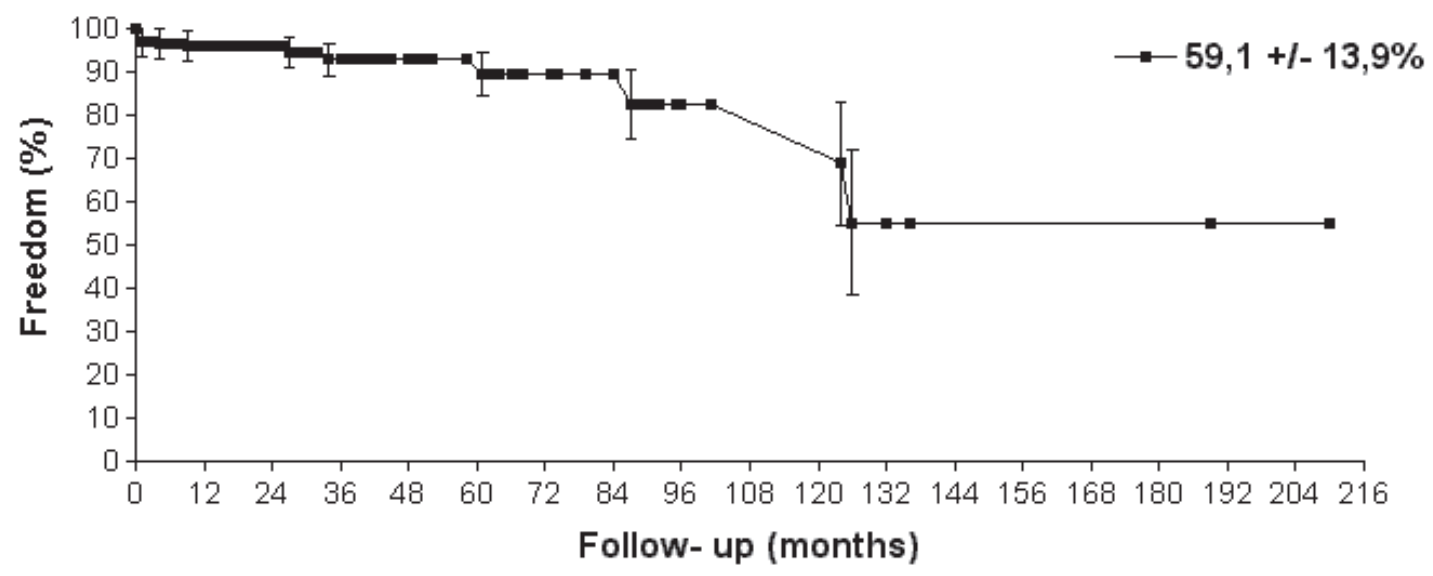

Figure 3 - Actuarial freedom from reoperation ( $\%+/$ - Standard Error)

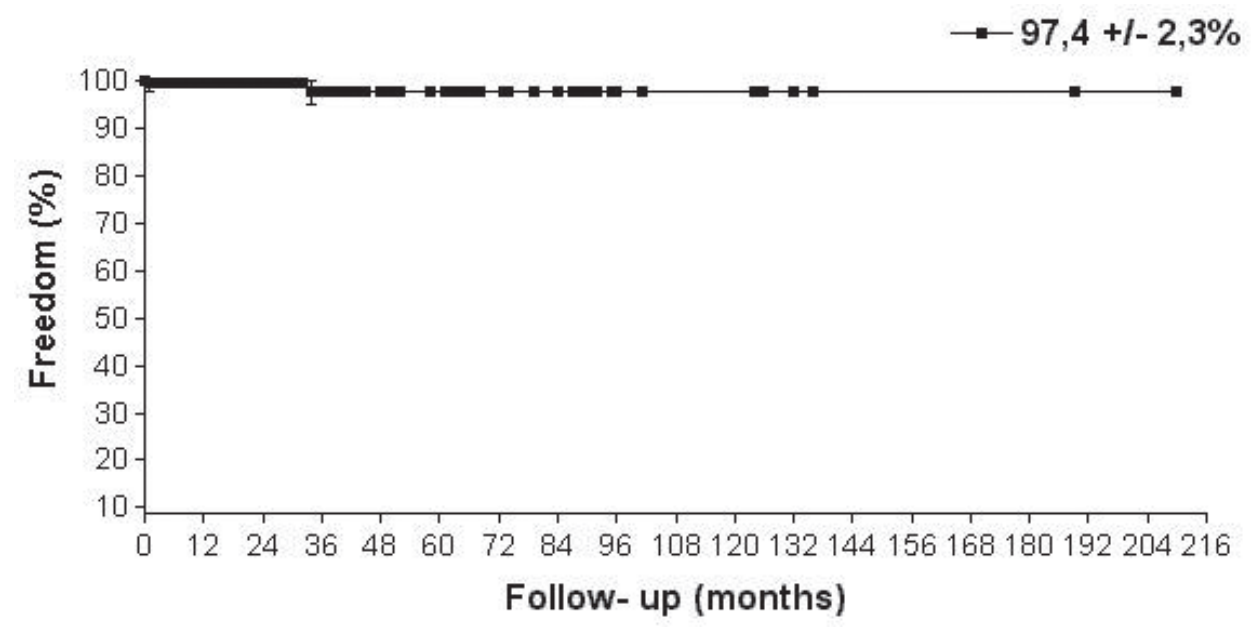

Figure 4 - Actuarial freedom from thromboembolism (\% +/- Standard Error) 


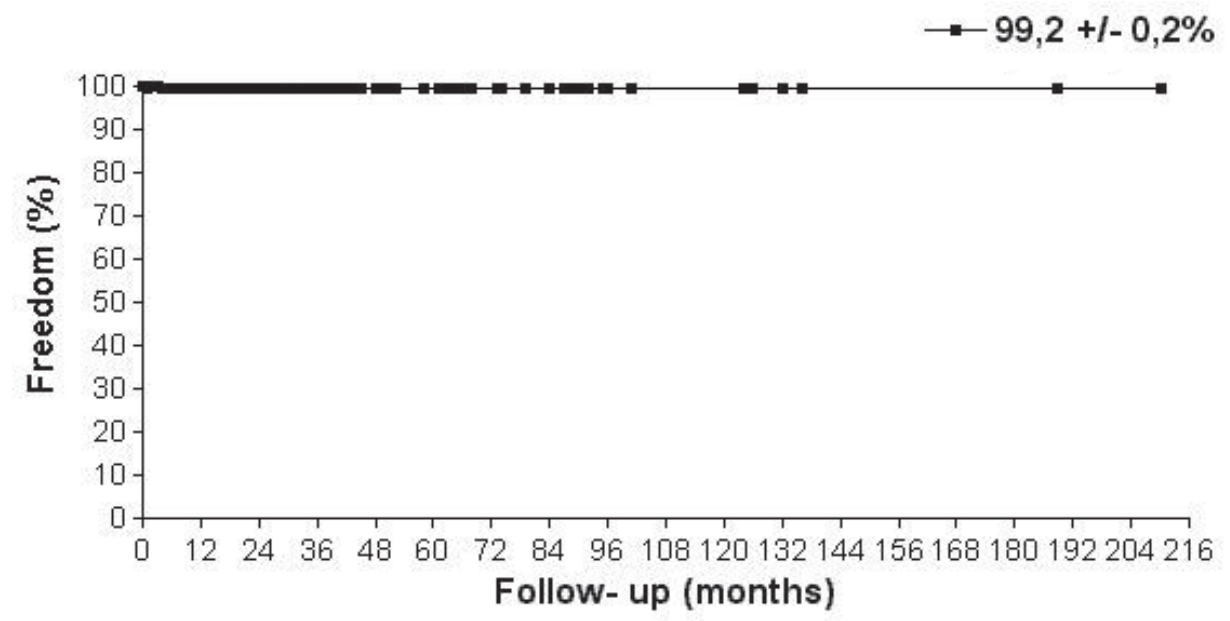

Figure 5 - Actuarial freedom from hemolysis $(\%+/$ - Standard Error)

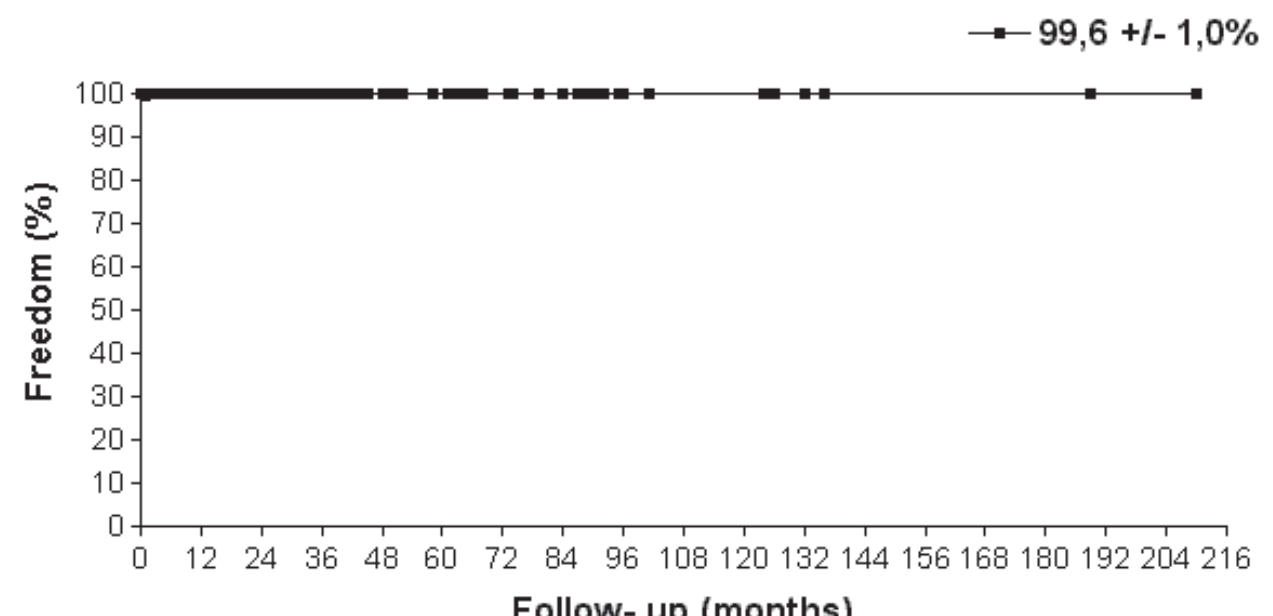

Figure 6 - Actuarial freedom from endocarditis (\% +/- Standard Error)

in mitral regurgitation is intended to preserve the anatomical and physiological characteristics of the mitral annulus, ${ }^{14,15}$ since we know that the use of prosthetic rings, especially the rigid ones, impedes normal contraction of the annulus. ${ }^{16}$ The clinical and echocardiographic results with flexible mitral annuloplasty are well established in the literature. ${ }^{6,17}$

Our late results were comparable with other reported series, with low rates of late events as presented by Duran et al. ${ }^{18}$ and Skoularigis. ${ }^{19}$ Freedom from reoperation of $59.1 \%$ in 18 years is reasonable, considering the prevalence of rheumatic disease in these patients. We should also emphasize the great number of associated procedures of valve repair ${ }^{20}$ and associated operations ${ }^{21}$ employed in this series that were identified in the literature as risk factors for reoperation in the late postoperative period.

The use of associated techniques with valve repair, such as chordal shortening, anterior leaflet resection, and papillary muscle splitting must be accompanied by careful intraoperative decision-making and should be performed by an expert surgeon. ${ }^{9,22}$ In rheumatic patients, we repair valves when we judge that the repair will restore satisfactory function to the valve, especially when the anterior leaflet is pliable. In rupture of anterior leaflet chordae, triangular resection associated with posterior annuloplasty is feasible and simple, as demonstrated by others. ${ }^{23,24}$

Similar to our own findings, reported rates of thromboembolism or endocarditis after mitral valve repair have been low. According to Perier et al., ${ }^{25}$ most of the thromboembolic events occur during the immediate postoperative period, as shown in our series.

\section{CONCLUSIONS}

The use of a bovine pericardial strip for posterior annuloplasty presents some advantages on the annuloplasty rings, even the flexible ones, such as the low cost, the disposability of the material in hospitals, and the ease of handling the bovine pericardium tissue. The technique allows correction of the annulus and prevents further annular dilatation. 
Pomerantzeff PMA, Brandão CM de A, Albuquerque JMA, Pomerantzeff PY, Takeda F, Oliveira SA. Anuloplastia mitral com tira de pericárdio bovino resultados de 18 anos. Clinics. 60(4):305-10.

OBJETIVO: Anéis protéticos para anuloplastia são usados nas plásticas da valva mitral de forma rotineira. A anuloplastia posterior com tira de pericárdio bovino é uma técnica largamente utilizada no Instituto do Coração - HC - FMUSP. O objetivo deste estudo foi analisar os resultados tardios da plástica da valva mitral com a utilização desta técnica na nossa instituição.

MÉTODOS: Entre janeiro de 1984 e dezembro de 2002, 273 pacientes foram submetidos a plástica da valva mitral com anuloplastia posterior no Instituto do Coração. Foram excluídos os pacientes submetidos a outros procedimentos no anel posterior. Cento e quarenta e quatro $(52,7 \%)$ eram do sexo feminino e a idade variou entre 1 e 76 anos (média: 38,3 $\pm 21,1$ anos). Em 52\% dos pacientes, havia história de febre reumática. Técnicas associadas para reconstrução valvar foram empregadas em $26 \%$ dos casos, sendo a mais utilizada, o encurtamento de cordas $(9,2 \%)$.

RESULTADOS: A mortalidade hospitalar foi de 3,3\% (9 casos). A principal causa de óbito foi baixo débito cardíaco (6 pacientes). A sobrevida actuarial foi de 55,1 $\pm 16,8 \%$ (percent +/- Standard Error) em 18 anos, sobrevida livre de reoperação, tromboembolismo, hemólise e endocardite foram respectivamente de 59,1 $\pm 13,9 \%, 97,4 \pm 2,3 \%, 99,2$ $\pm 0,2 \%, 99,6 \pm 1,0 \%$ em 18 anos. No seguimento tardio, $83,9 \%$ dos pacientes se encontravam em classe funcional I (NYHA).

CONCLUSÕES: Concluímos que os resultados tardios foram satisfatórios. A técnica é fácil, reprodutível e de baixo custo.

\section{UNITERMOS: Valva mitral. Anuloplastia. Cirurgia valvar. Pericardio bovino. Plástica valvar.}

\section{REFERENCES}

1. Carpentier A. Cardiac valve surgery - the "French correction". J Thorac Cardiovasc Surg. 1983;86:323-7.

2. Davis PKB, Kinmonth JB. The movements of the annulus of the mitral valve. J Cardiovasc Surg. 1963;4:427-31.

3. Cosgrove DM 3rd, Arcidi JM, Rodriguez L, Stewart WJ, Powell K, Thomas JD. Initial experience with Cosgrove-Edwards Annuloplasty System. Ann Thorac Surg. 1995;60:499-504.

4. Carpentier AF, Lessana A, Relland JY, Belli E, Mihaileanu S, Berrebi $\mathrm{AJ}$, et al. The "physio-ring": an advanced concept in mitral valve annuloplasty. Ann Thorac Surg. 1995;60:1177-86

5. Scrofani R, Moriggia S, Salati M, Fundaro P, Danna P, Santoli C. Mitral valve remodeling: long-term results with posterior pericardial annuloplasty. Ann Thorac Surg. 1996;61:895-9.

6. Volpe MA, Braile DM, Vieira RW, Souza DRS. Mitral valve repair with a malleable bovine pericardium ring. Arq Bras Cardiol. 2000, 75(5):389- 96

7. Edmunds LH Jr, Clark RE, Cohn LH, Grunkemeier GL, Miller DC, Weisel RD. Guidelines for reporting morbidity and mortality after cardiac valvular operations. Ad Hoc Liaison Committee for Standardizing Definitions of Prosthetic Heart Valve Morbidity of The American Association for Thoracic Surgery and The Society of Thoracic Surgeons. J Thorac Cardiovasc Surg. 1996;112(3):70811.
8. Pomerantzeff PM, de Almeida Brandao CM, Stolf NA, de Oliveira SA. Valve reconstruction in the Heart Institute of São Paulo, Brazil. Semin Thorac Cardiovasc Surg. 2002;14:324-27.

9. David TE. The appropriateness of mitral valve repair for rheumatic mitral valve disease. J Heart Valve Dis. 1997;6:373-4.

10. Antunes MJ. Mitral valvuloplasty, a better alternative. Comparative study between valve reconstruction and replacement for rheumatic mitral valve disease. Eur J Cardiothorac Surg. 1990;99:990-1001.

11. Pomerantzeff PM, Brandao CM, Faber CM, Grinberg M, Cardoso LF, Tarasoutchi F, et al. Mitral valve repair in rheumatic patients. Heart Surg Forum. 2000;3(4)273-6.

12. Pomerantzeff PMA, Snitcovsky R, Trevisan IV, Marcial MB, Verginelli G, Jatene AD. Surgical treatment of acute episodes of rheumatic fever. Cardiol Young. 1992;2:244-6.

13. Bernal JM, Rabasa JM, Vilchez FG, Cagigas JC, Revuelta JM. Mitral valve repair in rheumatic disease. The flexible solution. Circulation. $1993 ; 88(1): 1746-53$

14. Salati M, Scrofani R, Santoli C. Posterior pericardial annuloplasty: a physiological correction? Eur J Cardiothorac Surg. 1991;5:2269.

15. Pellegrini A, Quaini E, Colombo T, Lanfranchi M, Russo C, Vitali E. Posterior annuloplasty in the surgical treatment of mitral insufficiency. J Heart Valve Dis. 1993;2:633-8. 
16. David TE, Komeda M, Pollick C, Burns RJ. Mitral valve annuloplasty: the effect of the type on left ventricular function. Ann Thorac Surg. 1989;47:524-8.

17. Camilleri LF, Miguel B, Bailly P, Legault BJ, D'Agrosa-Boiteux MC, Polvani GL, et al. Flexible posterior mitral annuloplasty: five-year clinical and Doppler echocardiographic results. Ann Thorac Surg. 1998;66:1692-7.

18. Duran CG, Revuelta JM, Gaite L, Alonso C, Fleitas MG. Stability of mitral reconstructive surgery at 10-12 years for predominantly rheumatic valvular disease. Circulation. 1988;78(suppl I):91-6.

19. Skoularigis J, Sinovich V, Joubert G, Sareli P. Evaluation of the long-term results of mitral valve repair in 254 young patients with rheumatic mitral regurgitation. Circulation. 1994;90(suppl II):16774.

20. Gillinov AM, Cosgrove DM, Lytle BW, Taylor PC, Stewart RW, McCarthy PM, et al. Reoperation for failure of mitral valve repair. J Thorac Cardiovasc Surg. 1997;113:467-75.
21. Fernandez J, Joyce DH, Hirschfeld K, Chen C, Laub GW, Adkins MS, et al. Factors affecting mitral valve reoperation in 317 survivors after mitral valve reconstruction. Ann Thorac Surg. 1992;54:4408 .

22. Sanders JH, Scott ML. Pitfalls in surgical decision- making during mitral valve repair. Curr Opin Cardiol. 2001;16:140-5.

23. Fasol, R; Hubner, EJ. Triangular resection of the anterior leaflet for repair of the mitral valve. Ann Thorac Surg. 2001,71:381-3.

24. Alvarez JM, Teoh N, Deal CW. Repairing the degenerative anterior mitral leaflet. Ann Thorac Surg. 1992;54:1229-30.

25. Perier P, Stumpf J, Götz C, Lakew F, Schneider A, Clausnizer B, et al. Valve repair for mitral regurgitation caused by prolapse of the posterior leaflet. Ann Thorac Surg. 1997;64:445-50. 